\title{
HRVAŠKA ZEMLJIŠKA POSEST V OBČINI LENDAVA KOT SESTAVINA MEJNE PROBLEMATIKE
}

\author{
Belec Borut*
}

Izvleček

UDK 911.3:347.235=863(497.4 Lendava)

Predstavljena je narava hrvaške zemljiške posesti v občini Lendava s poudarkom na zemljiščih ob Muri. Odmik reke od katastrskih meja, po katerih od leta 1991 poteka državna meja s Hrvaško, je povzročil težave pri njenem določanju in sožitju obmejnega prebivalstva. Enakovredna zamenjava dvolastniških zemljišč omogoča ustreznejši potek mejne črte po rečnem toku.

Ključne besede: Državna meja, zemljiško dvolastništvo, Slovenija.

\section{CROATIAN REAL ESTATES IN LENDAVA MUNICIPALITY AS A CONSTITUENT OF THE BORDER PROBLEMS}

\begin{abstract}
Presented is the nature of Croatian real estates in Lendava municipality, with the emphasis laid on the estates along the Mura. Since the Mura has shifted from cadastral borders which formed a basis for establishing the state border with Croatia in 1991, troubles have begun in determining this border and consequently, in the coexistence of the people living in these border areas. An equivalent exchange of the lands stretching beyond the state border provides for the more practicable borderline which follows the river course.
\end{abstract}

Key words: State border; Real estates stretching beyond the border; Slovenia.

"Dr., prof., Oddelek za geografijo, Pedagoška fakulteta Univerza v Mariboru, Koroška c. 160, SI 2000 Maribor, Slovenija 


\section{UVOD}

Med obmejnimi občinami severovzhodne Slovenije je hrvaška zemljiška posest v občini Lendava najizrazitejša. To velja zlasti za vasi neposredno ob hrvaški meji. Izstopata dve območji dokaj strnjene posesti - vinogradov v Lendavskih goricah ter njiv, travnikov in gozdov v mejnem pasu s Hrvaško ob Muri. Potek sedanje državne meje po upravnih mejah, tj. mejah katastrskih občin, je zaradi premikov struge postal neživljenjski, povzroča mnoge lokalne obmejne probleme ter zahteva ustrezne korekture. Spremeniti ga je mogoče $\mathrm{z}$ recipročno zamenjavo zemljišč in določitvijo nove meje po sedanjem živem ali reguliranem toku reke in to bi gotovo pripomoglo $\mathrm{k}$ oblikovanju ustreznejšega mejnega režima in odpravilo težave $v$ povezovanju obmejnega prebivalstva. Avstrijsko-ogrska meja tu ni potekala po Muri kot med Radgono in Ljutomerom, zato so bili stiki prebivalstva med Lendavskim Dolinskim in Hrvaškim Medjimurjem ob dolgoletni zgodovinski pripadnosti Ogrski zelo tesni. Zemljiška posest se je pomešala ne le v naseljih, ki leže neposredno ob Muri, temveč prav tako $\mathrm{v}$ vinorodnih Lendavskih goricah.

Prispevek prikazuje hrvaško zemljiško posest po letu 1991 v občini Lendava ter posebej v k.o. Petišovci, Pince, Hotiza in Dolina, ki se v pogledu dvolastništva znatno razlikujejo. Hkrati iz njega razberemo tip čezmejne zemljiške posesti v primerjavi z drugimi mejnimi območji severovzhodne Slovenije.

\section{SPREMEMBE TOKA IN REGULACIJA MURE}

Slovensko-hrvaška meja poteka $v$ občini Lendava po reguliranem toku in mrtvih meandrih Mure od slovensko- madžarsko-hrvaške tromeje ob izlivu Ledave v Krko do mejnega naselja Gibina $v$ občini Ljutomer, nedaleč od izliva Ščavnice. Naravni premiki reke in posegi v njen tok so znani že iz srednjega veka, zaradi katerih so na Murskem polju v 16. stol. izginile vasi Poljana, Pirovci, Pipovci in del sedanje Stare vasi, ki jih v 15. stol. še omenjajo (Kovačič, 1926). Tudi ogrski zakon iz leta 1655 je določal nadaljevanje gradnje nasipov za preprečitev poplav. Kasneje so regulacijska dela opravljali na temelju posnetka struge iz leta 1753 , ki ga je dala predvsem zaradi plovbe izdelati Marija Terezija. Leta 1810 so presekali meander pri Razkrižju. Znano je, da je leta 1822 reka pri Murskem Središču zapustila staro strugo in si na levem bregu izdelala novo. Tamkajšnji most je ostal na suhem, vendar so Muro naslednje leto vrnili v prvotno korito. Pomembna je bila tudi gradnja razbremenilnega kanala Ledava - Krka in prestavitev izliva Ledave v Krko okrog leta 1850.

V obdobju 1847-91 so Muro regulirali do Veržeja, naprej pa so dela le počasi napredovala in niso mogla preprečiti vsakoletnih poplav. Leta 1935 je pri Dolnji Bistrici in Hotizi spremenila tok in obstajala je nevarnost, da se bo vrnila $\mathrm{v}$ staro 
strugo. Posebno visoka voda je nastopila maja 1938, ko je Mura poplavila zemljišča številnih muropoljskih vasi.

Leta 1958 je pričel delovati razbremenilni kanal Ledava - Mura, postopoma pa so regulirali in zajezili tudi pritoke Mure. Zgradili so visokovodne obrambne nasipe pri Dolnji Bistrici, Razkrižju in na odseku Lakoš-Kot ter rekonstruirali nasip med Petišovci in Benico. Muro na odseku Hotiza - Kot - Gaberje so regulirali leta 1974, med Gaberjem in Lakošem pa v obdobju 1975-80. Takrat so uredili tudi izlivni odsek Ščavnice pri Razkrižju (Podlesek, 1985).

Zaradi odmika Mure od katastrskih meja so bili obrambni nasipi na levem bregu reke zgrajeni tudi na ozemlju hrvaških katastrskih občin, npr. pri Hotizi in Petišovcih. Do leta 1991 je namreč veljalo načelo, da obe državi urejujeta brežine vsaka na svojem bregu ne glede na potek občinske oziroma republiške meje. Ker Hrvaška obrambnih nasipov ne vzdržuje grozi nevarnost poplav.

\section{POTEK SLOVENSKO HRVAŠKE MEJE NA MURI}

Pri določanju državnih meja se $\mathrm{v}$ mednarodni praksi uporabljajo različni kriteriji in merila, med njimi upravne in naravne meje, kot so meje katastrskih občin in vodotoki. Večkrat se upoštevajo tudi zgodovinski, geografski, gospodarski, prometni, ekološki in podobni kriteriji, tik ob mejni črti tudi želje in potrebe prebivalstva. Izhodišče za določitev meje med Slovenijo in Hrvaško je upoštevanje njihovega stanja na dan 25. junija 1991. Najpomembnejši kriterij pri tem so po dogovoru ekspertnih skupin obeh držav leta 1992 na Otočcu občinske oz. katastrske meje, vendar je Slovenija kot dopolnilni kriterij predlagala tudi smiselno upoštevanje naravnih meja po vodotokih. Ob geodetski primerjavi katastrskih meja pa so bila zaradi dvojne lastniške evidence in geodetsko izpuščenih območij ugotovljena neskladja, ki zahtevajo predhodno uskladitev, novo določitev mejne črte na reki in zamenjavo zemljišč (Graj, 1997).

Zaradi odmika rečnega toka od katastrskih meja kot posledici meandiranja in regulacij danes državna meja večkrat prestopi reko. Na območju tromeje preide na levi breg in v ozkem pasu celo seka k.o. Pince, pri Podturnu, kjer je blizu 7 ha slovenskega ozemlja, pa se globoko zaje na hrvaško stran. Manjše površine so še med Ferketincem in Križevcem, Petišovci in Murskim Središčem ter Gaberjem in Hlapičino. Ob tem ugotavljamo, da je potek meje na Pregledni karti občine Čakovec in karti Županija Medjimurska v primerjavi s Pregledno karto občine Lendava in Atlasom Slovenije občutno generaliziran na račun slovenskega ozemlja.

Med Murskim Središčem in Hotizo se meja močno zaje na slovensko stran. Pri Hotizi in Kapci sega do prvih vaških hiš in magistralne ceste Murska Sobota - Lendava, na odseku od Hlapičine do Murskega Središča, kjer poteka po sredi mostu čez Muro, pa trikrat prestopi levi breg (sl.1). 
Slika1: Meja na starem meandru pri Petišovcih

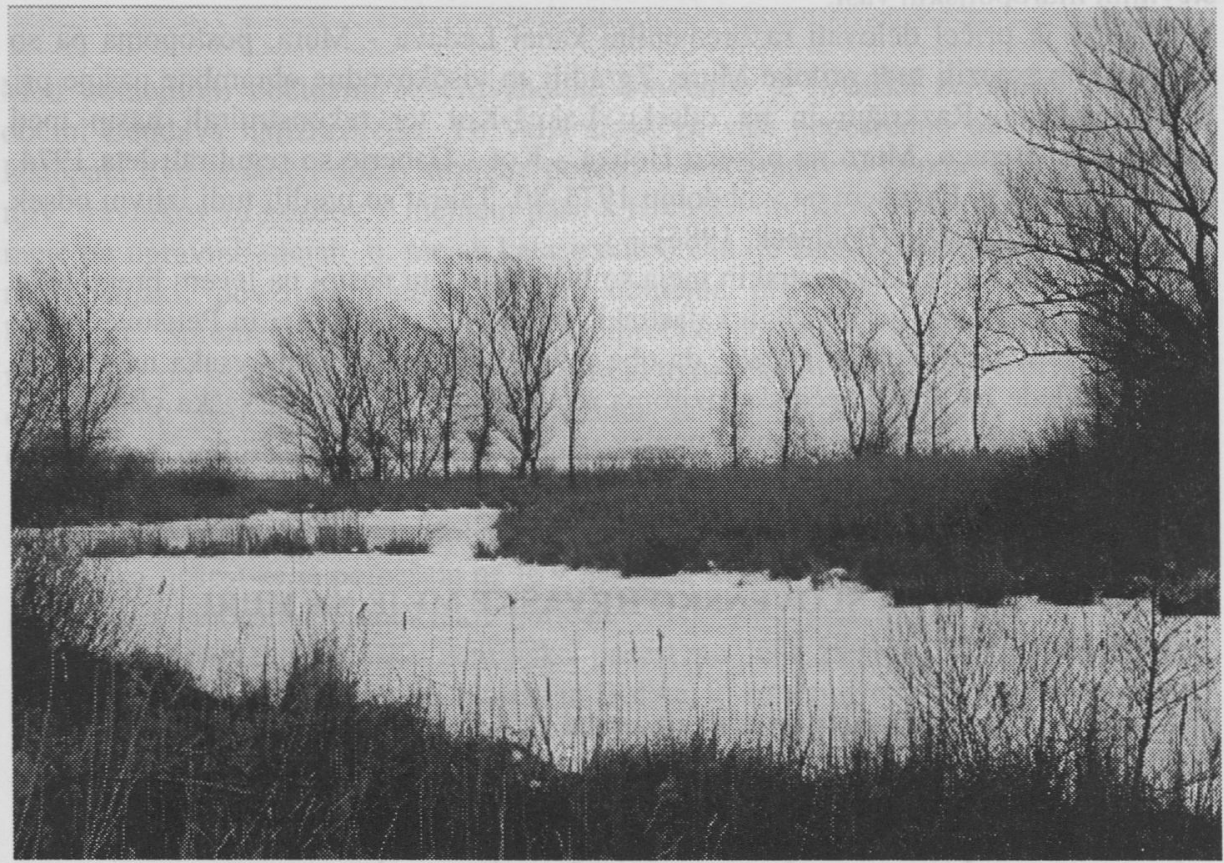

\section{ZEMLJIŠKO DVOLASTNIŠTVO V OBČINI LENDAVA}

V lendavski občini je leta 1992 imelo 2963 zemljiških lastnikov iz Hrvaške 805 ha zemlje ali $3.1 \%$ površine. Pri tem so zavzemale 360 ha njive, 5 ha sadovnjaki, 104 ha vinogradi, 228 ha travniki, 46 ha pašniki, 18 ha gozdovi in 44 ha nerodoviten svet. $\mathrm{Na}$ posestnika je odpadlo 0.27 ha zemlje. Od 34 k.o. je bila hrvaška posest razširjena v 23 občinah. V dveh k.o. je njen delež presegel $10 \%$ površine, $v$ dveh je znašal od 2 do 5 $\%$, v štirih od 1 do $2 \%$, v dveh od 0.5 do $1 \%$ in v trinajstih manj kot $0.5 \%$ (Belec, 1993). Izstopale so zlasti k.o. Pince, Petišovci, Dolina, Dolnja Lendava, Gaberje in Čentiba. Pri kasnejših analizah, ki so zajele tudi mešano slovensko-hrvaško posest, se je izkazalo, da je teh zemljišč več. V k.o Pince, Petišovci in Dolina merijo 866 ha, od tega je 414 ha njiv, 4 ha sadovnjakov, 55 ha vinogradov, 229 ha travnikov, 104 ha pašnikov, 15 ha gozda in 45 ha nerodovitnega sveta. Njihov delež je zelo visok, saj dosega $27 \%$ njiv, $9 \%$ sadovnjakov, $51 \%$ vinogradov, $43 \%$ travnikov, $44 \%$ 
pašnikov, $8 \%$ gozda in $10 \%$ nerodovitnega sveta ali četrtino skupne površine teh občin.

Podatki o obsegu slovenske posesti na Hrvaškem niso bili dostopni, znano je le število lastnikov. Iz 24 k.o. je imelo na Hrvaškem zemljo okoli 800 lastnikov, med njimi več kot 600 z Dobrovniškega in Osrednjega Dolinskega, zvečine iz Hotize, Velike in Male Polane, Kapce, Dolnje in Gornje Bistrice ter Odrancev (karta 1).

Karta 1. Zemljiški lastniki iz občine Lendava na Hrvaškem

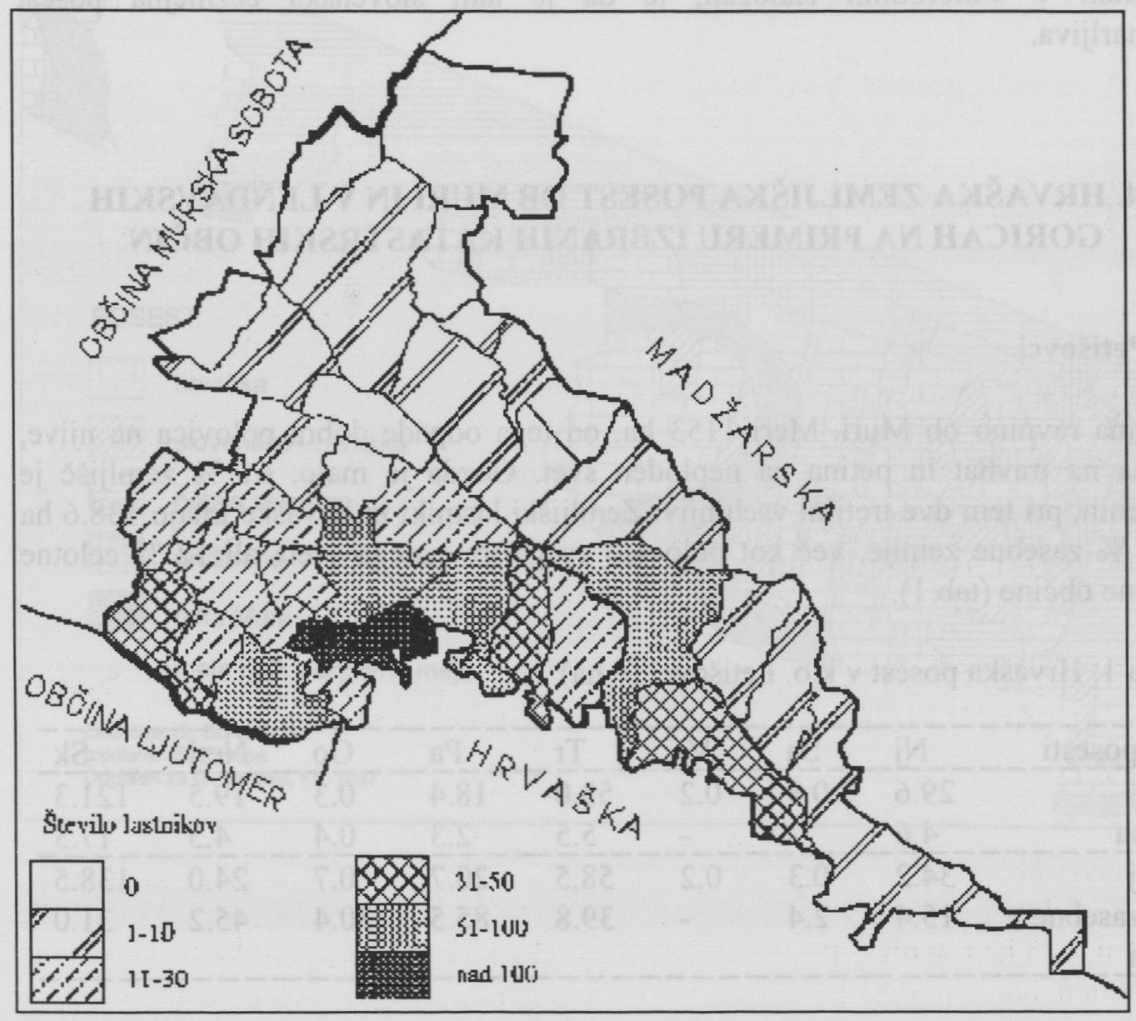

Pomen čezmejne hrvaške posesti $v$ občini Lendava je razviden iz njenega nadpovprečnega deleža $\mathrm{v}$ primerjavi $\mathrm{z}$ drugimi mejnimi občinami $\mathrm{v}$ severovzhodni Sloveniji. Njena osredotočenost v Lendavskih goricah oz. na Lendavskem Dolinskem predstavlja po metodologiji dvolastništva (Belec, 1996) tip močne, tj. stoodstotne razširjenosti in visokega deleža hrvaške posesti, saj je zastopana v vseh devetih k.o. tega območja. V štirih k.o. je njen delež nizek ( do $2 \%$ ), v treh zmeren ( 2 do $5 \%$ ) in $\mathrm{v}$ dveh visok (nad $10 \%$ ). Na Dobrovniškem in Osrednjem Dolinskem hrvaške posesti ni veliko. Med 25 k.o. tega območja zavzema v širinajstih manj kot $0.5 \%$ površine, $\mathrm{s}$ šestinpetdesetno odstotno razširjenostjo pa ga uvrščamo v tip zmerne razširjenosti z 
nizkim deležem hrvaških zemljišč. Lendavsko Dolinsko lahko primerjamo $\mathrm{z}$ razmerami na območju Razkrižja v Slovenskem Medmurju, le da tam ni občin z nizkim deležem, Dobrovniško in Osrednje Dolinsko pa s tistimi na Murskem polju, v Spodnji Ščavniški dolini in Zahodnih Ljutomersko-ormoških goricah. Lendavsko občino kot celoto lahko tako prištevamo $\mathrm{k}$ tipu zmerne razširjenosti hrvaške posesti s prevlado njenega nizkega deleža ter $\mathrm{z}$ manjšo zastopanostjo zmernega in visokega deleža. Hrvaško posest ima 23 ali $68 \%$ k.o., 18 k.o. je z nizkim, tri so z zmernim in dve z visokim deležem. Kot dvolastniški zemljiški tip je občina Lendava še najbliže razmeram v Vinorodnih Halozah, le da je tam slovenska čezmejna posest zanemarljiva.

\section{HRVAŠKA ZEMLJIŠKA POSEST OB MURI IN V LENDAVSKIH GORICAH NA PRIMERU IZBRANIH KATASTRSKIH OBČIN}

\section{K.o. Petišovci}

Zavzema ravnino ob Muri. Meri 1153 ha, od tega odpade dobra polovica na njive, četrtina na travnat in petina na neploden svet. Gozda je malo. $61 \%$ zemljišč je družbenih, pri tem dve tretjini vseh njiv. Zemljiški lastniki iz Hrvaške imajo 138.6 ha ali $31 \%$ zasebne zemlje, več kot polovico vsega travnatega sveta ali $12 \%$ celotne površine občine (tab.1).

Tabela 1: Hrvaška posest v k.o. Petišovci (v ha)

\begin{tabular}{|c|c|c|c|c|c|c|c|c|}
\hline Vrsta posesti & $\mathrm{Nj}$ & $\mathrm{Sa}$ & Vi & $\operatorname{Tr}$ & $\mathrm{Pa}$ & Go & Nerl & Sk \\
\hline Čista & 29.6 & 0.3 & 0.2 & 53.0 & $\overline{18.4}$ & $0 . \overline{3}$ & 19.5 & 121.3 \\
\hline Mešana & 4.6 & - & - & 5.5 & 2.3 & 0.4 & 4.5 & 17.3 \\
\hline Skupaj & 34.2 & 0.3 & 0.2 & $58 . \overline{5}$ & 20.7 & $0 . \overline{7}$ & 24.0 & 138.5 \\
\hline$\%$ od zasebne & 15.4 & 2.4 & - & 39.8 & 85.5 & 30.4 & 45.2 & 31.0 \\
\hline
\end{tabular}

Vir: Cafnik, 1995.

Lastnikov iz Hrvaške je 722, pretežno iz medjimurskih naselij Križovca (311), Čakovca (133), Murskega Središča (132), Peklenice 97, Vratišinca (35) in Miklavca (32). Tri četrtine gospodinjstev ima manj kot 0.5 ha zemlje. Zemljišča leže zvečine ob Muri, kjer katastrska meja med k.o. Petišovci in Križovec večkrat prestopi rečni tok. Najbolj sklenjena so v neposredni bližini Križovca in Peklenice, odkoder je skupaj 408 ali več kot polovica lastnikov. Dostop do zemljišč omogoča križovski brod. Zemljo na Hrvaškem ima 46 prebivalcev Petišovec (karta 2). 
Karta 2: Hrvaška posest med Petišovci in Križovcem.

Primer zapletenega poteka državne meje ob Muri, kjer katastrske meje v zračni razdalji $5 \mathrm{~km}$ petkrat preidejo na levi in trikrat na desni breg reke. K.o. Petišovci.

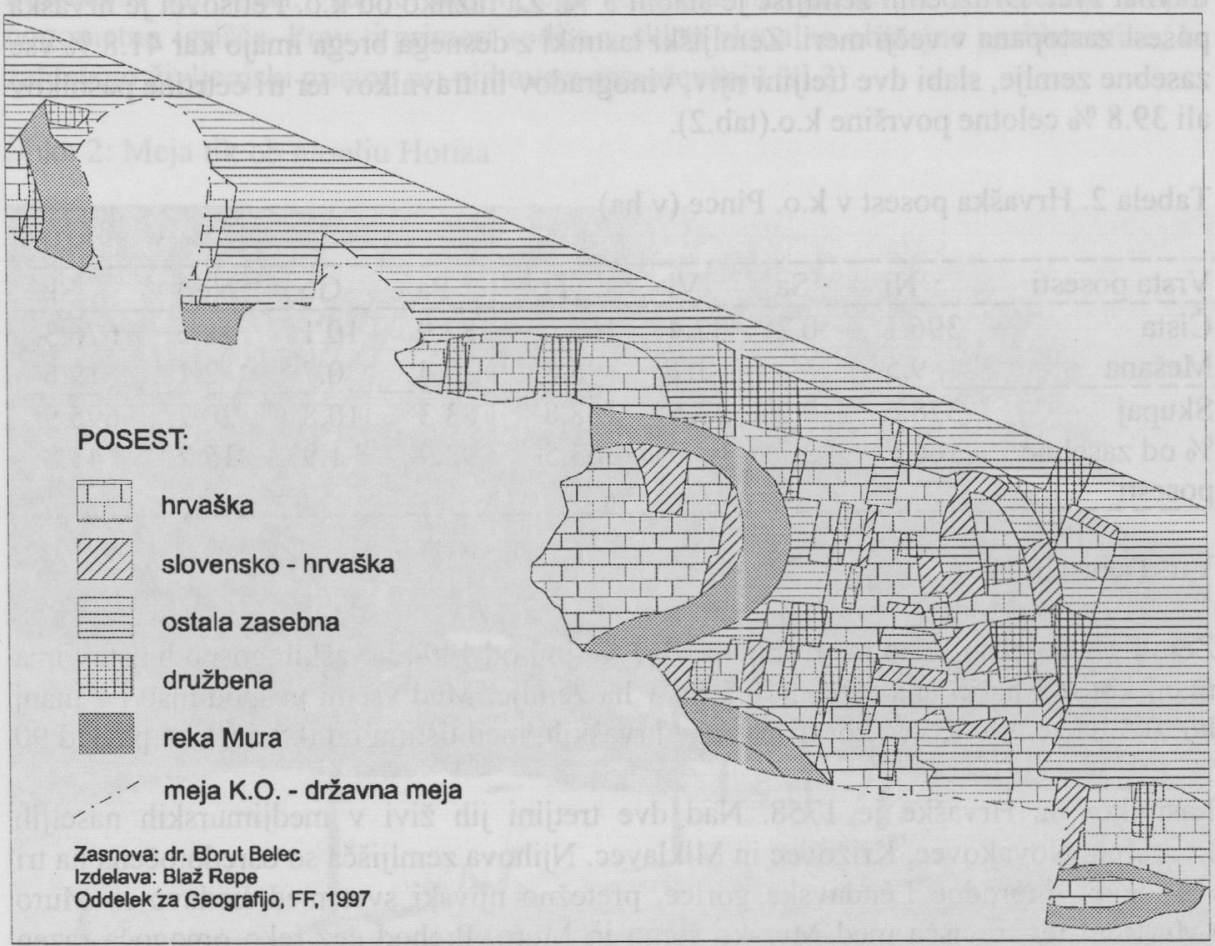




\section{K.o. Pince}

Občina s površino 1746 ha, stisnjena med slovensko- hrvaško mejo na Muri in slovensko-madžarsko mejo na Ledavi, je pretežno ravninska, sega pa tudi še v skrajni konec Lendavske goric. Okoli tretjino površine zavzemajo njive in gozdovi, petino travnat svet. Družbenih zemljišč je slabih $5 \%$. Za razliko od k.o. Petišovci je hrvaška posest zastopana $v$ večji meri. Zemljiški lastniki z desnega brega imajo kar 41.8 \% vse zasebne zemlje, slabi dve tretjini njiv, vinogradov in travnikov ter tri četrtine pašnikov ali $39.8 \%$ celotne površine k.o.(tab.2).

Tabela 2. Hrvaška posest v k.o. Pince (v ha)

\begin{tabular}{|c|c|c|c|c|c|c|c|c|}
\hline Vrsta posesti & _- $\mathrm{Nj}$ & $-\underline{S a}$ & Vi & Tr & $\mathrm{Pa}$ & - Go & Nerl & Sk \\
\hline Čista & 396.1 & 0.2 & 32.4 & 163.0 & 82.9 & 10.1 & 18.6 & $6 \overline{7} 6.3$ \\
\hline Mešana & 9.5 & - & 1.1 & 5.8 & 0.4 & 0.7 & 2.1 & 19.6 \\
\hline Skupaj & 378.6 & 0.2 & 33.5 & 168.8 & 83.3 & 10.8 & 20.7 & 695.9 \\
\hline $\begin{array}{l}\% \text { od zasebne } \\
\text { posesti }\end{array}$ & 66.7 & 2.7 & 60.0 & 63.5 & 92.9 & 1.9 & 15.2 & 41.8 \\
\hline
\end{tabular}

Vir: Deutsch, 1996.

Zemljišča so ekstremno razdrobljena, dve tretjini od 1494 hrvaških gospodinjstev ima manj kot 0.5 ha in ena četrtina 0.5 do 1 ha zemlje. Med vsemi gospodinjstvi z manj kot 0.5 ha zemlje je več kot tri četrtine hrvaških, med tistimi od 0.5 do 1 ha pa nad 90 $\%$.

Lastnikov iz Hrvaške je 1758. Nad dve tretjini jih živi v medjimurskih naseljih Podturen, Novakovec, Križovec in Miklavec. Njihova zemljišča so osredotočena na tri območja: vinorodne Lendavske gorice, pretežno njivski svet med Ledavo in Muro (Murišča) ter travišča med Mursko šumo in Muro. Prehod čez reko omogoča razen tistega pri Križovcu brod pri Podturnu. Čezmejno posest ima le pet vaščanov Pinc.

\section{K.o. Hotiza}

Podobno kot Pince in Petišovci je tudi Hotiza mejno naselje ob Muri. Njen tok se je tod prestavil proti jugu, državna meja pa poteka po starem rečnem rokavu $\mathrm{v}$ neposredni bližini naselja in cestnih povezav. Po njem je bila začrtana katastrska meja že v preteklem stoletju, kar med drugim dokazuje katastrski načrt iz leta 1864 . Ker mrtvi meander ni predstavljal posebne naravne ovire, se je vaško zemljišče kot nekakšna eksklava razširilo čezenj, tj. v hrvaško k.o. Martin na Muri, skupna administrativna pripadnost obeh bregov Mure Ogrski pa je takšen razvoj še pospeševala. 
Zemljo na Hrvaškem ima 225 lastnikov, med njimi nekateri vinograde v Medjimurskih goricah, hrvaških lastnikov v k.o. Hotiza pa je komaj 7 s skupaj 0.8 ha zemlje (Prendl, 1993). Muro so na tem odseku regulirali in zemljišča z obrambnimi nasipi zaščitili pred poplavami. Na njem leži pet hišnih številk Hotize (zaselek Brezovec) s slovenskim življem, čez pa vodi dostop do broda, ki povezuje naselje z Martinom na Muri. Tu je razen tega locirana betonarna in v sosednji Kapci nogometno igrišče. Prav ti primeri sodijo v sklop aktualne obmejne problematike, ki zahtevajo življenjski pristop pri njihovem razreševanju (sl.2).

Slika 2: Meja tik ob naselju Hotiza

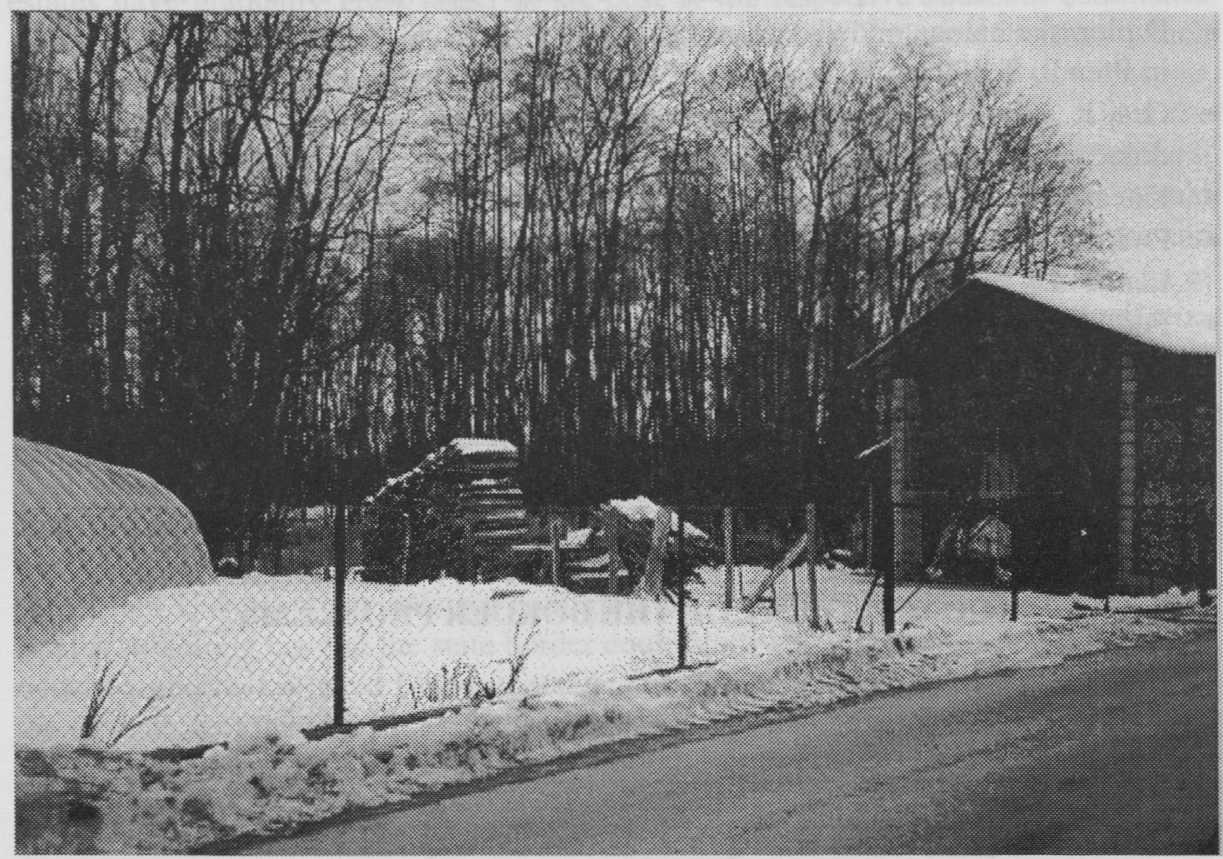

\section{K.o. Dolina}

Zavzema del Dolinskega in Lendavskih goric. Od 668 ha je skoraj polovica v njivah, desetino zavzemajo vinogradi. Družbena je več kot polovica površin. Hrvaškim lastnikom pripada 21 ha ali tretjina vseh vinogradov, ki predstavljajo dve tretjini njihovih tukajšnjih zemljišč. Ta so zelo razdrobljena, za razliko od k.o. Pince pa tudi bolj lastniško pomešana. Zavzemajo 10 \% zasebnih zemljišč v katastrski občini. Med 1029 lastniki jih je 405 ali 39 \% iz Hrvaške, pretežno iz Križovca (66), Miklavca (52), Peklenice (47), Gornjega Kraljevca (44), Podturna (40), Murskega Središča (30), 
Ferketinca (28), Vratišinca (21), Čakovca (18) in Sivice (18). Razen treh imajo vsi manj kot 0.5 ha zemlje. Zemljo na Hrvaškem imata le dva lastnika (Prendl, 1993).

\section{VIRI IN LITERATURA}

- Belec B., 1993: Prekomejna zemljiškoposestna pomešanost in zaposlovanje primer obmejnih občin SV Slovenije s Hrvaško. Dela 10, Ljubljana, str. 75 -77.

- Belec B.. 1996: Tipi obmejnih območij ob slovensko-hrvaški meji v Spodnjem Podravju s Prlekijo. Spodnje Podravje s Prlekijo. Ljubljana, str. 318-319.

- Diplomske naloge oddelka za geografijo PEF : Cafnik, N. 1995, Deutsch, S. 1996 in Prendl, S. 1993.

- Graj R., 1997: Vidiki meje, pravne osnove, kriteriji, problematika in stališča pri določanju slovensko- hrvaške meje. Seminarska naloga. FAGG Ljubljana.

- Kovačič, F. 1926: Ljutomer. Zgodovina trga in sreza. Maribor, str.22, 252.

- Podatki o površini in lastništvu zemljišč za leto 1991. Geodetska izpostava Lendava.

- Podlesek K., 1985: Urejanje Mure, Lendave in Ščavnice. Razvoj vodnega gospodarstva Pomurja in Podravja.

- Vodnogospodarsko podjetje Maribor, str. 51-56.

\section{CROATIAN REAL ESTATES IN LENDAVA MUNICIPALITY AS A CONSTITUENT OF THE BORDER PROBLEMS}

\section{Summary}

Lendava municipality ranks among those border municipalities where the real estates stretching beyond the state border are quite numerous. Especially outstanding are the estates in the area along the border with Croatia, located by the Mura and in the Lendavske gorice vinegrowing hills. Their great number is due to historical reasons; namely within the Austro-Hungarian monarchy,, this territory was in Hungary, in Zala district, where the river was not delineating the Austrian and the Hungarian parts of the state. Thus, the lifes of the people on both banks of the Mura were closely connected from time immemorial. Also within the frame of Yugoslavia, all until the gaining of independence of Slovenia, the inner border between the provinces and later on, the border between Slovenia and Croatia on the Mura did not impede the contacts between the people living on the opposite banks. 
There are about 3000 Croatian land owners in Lendava municipality, with 900 ha of lands; their estates extend in two thirds of cadastral communes and in some of them, they occupy 2 to 10 percent of the area. Slovenian land owners in Croatia are fewer, about 800 , and their estates extend along the Mura and in the Medjimurske gorice vinegrowing hills.

That the real estates of the owners from the settlements along the Mura stretch beyond the state border is not only due to the proximity of these settlements, but also due to the Mura which shifted from the cadastral borders because of meandering and regulations. Parallel with the shifting of the river course, Slovenian and Croatian real estates have gradually grew larger at the cost of the respective cadastral communes located on the opposite bank of the Mura. The existing cadastral borders which originated in the past century on the living Mura river course have thus become impracticable after the gaining of independence of Slovenia and they affect the coexsistence of the border population, and among other things, also agricultural activities on the real estates stretching beyond the border. Therefore, a solution should be searched for in establishing more practicable course of the border line. In Pince and Petišovci cadastral communes which lie by the bordering Mura, there are 834 ha of lands owned by the people from the nearby Croatian settlements, while in Hotiza cadastral commune and in some other ones, a considerable percentage of Slovenian lands lies on Croatian territory. Therefore, based on equivalent exchange of lands, corrections of the state border would be sensible, particularly in those sections of the river where its natural or regulated course cuts through the bordering dead meanders and the real estates which stretch beyond the state border. A new borderline could thus be drawn on the living Mura course in certain narrower areas, without any significant changes of its existing configuration. Major changes in the ownership of estates stretching beyond the state border could start with a sale or exchange of lands, which would be triggered by an impracticable border regime. Thus, the strivings for the formation of the so-called open borders are even more important, because it would provide for the more favourable economic and cultural coexistence of the border population. 